\title{
A colonização, uma referência historicizante do discurso sobre a descolonização de África: uma provocação filosófica a partir de Frantz Fanon
}

\author{
Nlandu Matondo Faustino ${ }^{1}$
}

Resumo: O presente trabalho procurou desconstruir, a partir das teses de Frantz Fanon, sobretudo aquelas formuladas nos "Condenados da Terra", a ideia de uma suposta missão civilizadora subjacente na intenção colonizadora consubstanciada na equação "colonização igual a civilização e paganismo igual a selvageria”. Partindo de uma indagação da validade criticável da equação em epígrafe, cruzou os factos às doutrinas que versam sobre o fenómeno da colonização de África, e chegou a depreender, com uma certa objectividade, de que a colonização em África, tal ficou visto por Fanon, foi mais um movimento de despersonalização e de coisificação dos africanos em geral e, dos negros, em particular do que um projecto de humanização e de emancipação dos indígenas de África negra. Ficou, portanto evidente, ao longo deste trabalho, de que a colonização foi uma violência que extraiu a sua originalidade na substantivação do colonizado. Uma violência que, não só, presidiu ao arranjo do mundo colonial, como também, ritmou e alimentou a destruição antropológica e ontológica do negroafricano, incluindo todas as suas formas sociais; arrasou completamente os seus sistemas de referências económicas, os seus modos "essendi et operandi" e decretou a crise sócio-cultural dos povos negros de África.

Palavras chaves: Colonização. Civilização. Violência. Despersonalização. Descolonização. Emancipação.

\footnotetext{
${ }^{1}$ Doutorando em Filosofia na Universidade de Évora; Mestre em Ciências da Educação pela mesma Universidade; Mestre em Filosofia pela Universidade Gregoriana e Docente na Universidade Católica de Angola. E-mail: nlando.faustino@ucan.edu.
} 


\section{Introdução}

A reflexão em torno dos desafios da descolonização em África continua actual e actuante em qualquer discurso intelectual ou político sobre o estado da nação de muitos Estados africanos, passados que são, aproximadamente, seis décadas desde que muitos deles se tornaram independentes. Esta actualidade pode, todavia, não parecer evidente quando o enfoque do discurso for a colonização. De facto, pode parecer anacrónico e mesmo sintomático falar da colonização para tentar justificar, a qualquer preço, o subdesenvolvimento e a instabilidade sociopolítica, na actualidade, de muitos Estados africanos independentes. Bom ou malgrado, essa sensação de anacronismo que sugere uma espécie de époké, em torno do fenómeno colonial, perde a sua legitimidade na medida em que a pertinência do discurso sobre a descolonização de África torna, "ipsis verbi”, procedente o discurso sobre a colonização. Ou seja, toda a fala em torno da descolonização sugere, de uma ou de outra forma, uma incursão sobre a colonização. Vamos, ao longo deste trabalho, procurar descortinar o conceito de colonização na tentativa de perceber as diversas nuances que encerra e a natureza do trampolim que pode sugerir à nossa cogitação sobre a descolonização. Para o efeito, propomos a seguinte estrutura: 1. Em busca do justo significado do conceito de colonização a partir da analítica de Fanon; 2. Indagando sobre a validade criticável da equação colonização igual a civilização; 3. Do entendimento teórico dos conceitos em análise a uma possível dedução da sua correlação; 4. Da análise de algumas doutrinas e factos a uma possível verificação da equação de partida; 5 . A colonização como projecto de modernização de África: clarividência ou equívoco? 6 . Desconstruindo o mito de uma civilização humanista, erguida na recusa do humano enquanto diferente; 7. A compartimentação maniqueísta do mundo colonial - uma antítese à pretensão de uma suposta missão emancipadora dos africanos subjacente na intenção colonizadora. 


\section{Em busca do justo significado do conceito de colonização a partir da sua analítica em Fanon}

Não é possível falar da descolonização em Fanon, sem falar da colonização, enquanto referência inofuscável e movimento historicizante que confere corpo e sentido, matéria e forma a qualquer análise crítica do projecto de descolonização de África. Esta é, de resto, a lógica que suporta o argumento de Fanon, que passamos a transcrever:

a descolonização [...] é um processo histórico [...], não pode ser compreendida, não encontra a sua inteligibilidade, não se torna transparente para si mesma, senão na exacta medida em que se faz discernível o movimento historicizante que lhe dá forma e conteúdo - a opressão colonial. (Fanon, 1968, p. 26 ou Fanon, 2002, p. 452).

Desde esta perspectiva, a análise sobre a colonização ganha uma particular relevância, na medida em que se nos apresenta, não só, como fundamento a partir do qual se pode erguer qualquer avaliação sobre as metas e objectivos que configuram o horizonte teleológico da luta dos africanos, rumo à sua efectiva emancipação e reintegração no universalismo humano, mas, também, como pretexto para (re)pensar o caminho de superação das novas formas de colonização que grassam ainda África e que, em si, constituem um verdadeiro impasse para uma descolonização efectiva do continente africano. Importa, desde já, sublinhar que esta reflexão de tipo histórico não encontra o seu real significado na descrição dos factos que ela encerra, nem na narração histórica que a constitui. $\mathrm{O}$ seu real alcance reside na sua capacidade de sugerir um conjunto de questionamentos em torno deste grande desiderato - a descolonização - vislumbrado pelos africanos, passados que são cinquenta e sete anos, após a morte de Fanon. 
Tem-se, com efeito, e não poucas vezes, associado a colonização de África a um projecto civilizador ou modernizador que terá sido frustrado ou interrompido por uma espécie de ambição irracional dos africanos, admitindo-se, deste modo, a hipótese segundo a qual a colonização terá sido um "projecto interrompido" de civilização (modernização) da África e dos africanos. De recordar que o "discurso sobre o colonialismo" de Aimé Césaire resulta, precisamente, da necessidade de dissertar sobre uma possível analogia entre a "colonização e a civilização". Provocação ou não, mas o simples facto de lhe ter sido solicitado, discorrer sobre o binômio colonização-civilização pelo Franco-Senegalês Alioune Diop, fundador e Director da Revista "Présence Africaine" em Paris, 1950, insinua a existência de tendências que aproximavam a colonização à civilização. Esta provocação, tal como nos parece ser, não deixa de ser, no plano metodológico, um bom ponto de partida para uma discussão mais objectiva e crítica da concepção fanoniana do colonialismo, porquanto nos permite lançar a discussão levantando uma série de perguntas, tais como: 1. É possível sustentar, por via de argumentação, uma provável analogia entre os dois conceitos em análise, a saber: colonização e civilização? 2. Terá havido, realmente, um plano colonial de civilizar ou modernizar a África em proveito dos africanos? 3. Era sensato legitimar a opressão colonial a partir dos progressos alcançados nas colónias de África durante a administração colonial? Dito de outro modo - Será que os níveis de desenvolvimento conseguidos em vários domínios: social, administrativo, tecnológico e político, sob o regime colonial, conferiam, efectivamente, a merecida dignidade à África e aos africanos? 4. Terá a África, realmente, recusado o desenvolvimento, como diria Axel Kabu, ao engajar-se na luta pela descolonização? 5 . E hoje, em plena era pós-colonial, poderão os africanos afirmar, com realismo, franqueza e frontalidade, que os ideais que nortearam o projecto da descolonização foram alcançados? 6. Terá alguma razão de ser o postulado, segundo o qual, o projecto de descolonização terá sido abortado, na sua menor idade, admitindo-se, deste modo, um 
possível equívoco entre os líderes e os intelectuais africanos que terão confundido as independências (enquanto meio) com a descolonização (enquanto fim da longa marcha, usando a expressão de René Dumont, rumo a um continente mais humano, mais livre, mais autónomo, mais justo, e mais próspero)?

Ao longo desta reflexão, tentaremos identificar alguns elementos de resposta a estas perguntas, tendo como principal suporte a obra de Frantz Fanon.

\section{Indagando sobre a validade criticável da equação colonização igual à civilização}

Qual terá sido o verdadeiro retrato do colonialismo: um processo de civilização dos chamados indígenas ou um "movimento de despersonalização e de coisificação" dos povos africanos? É evidente que, para Fanon, esta questão nem sequer merece ser colocada. De facto, o jovem martinicano é bastante incisivo e objectivo na sua análise. Para ele, a colonização é, antes de mais, uma "violência", conceito que, de resto, dá título ao $\mathrm{I}^{\mathrm{O}}$ capítulo do Les Damnés de la Terre (Fanon, 1968, p.23 ou 2002, p.448). Na sua óptica, a violência foi, precisamente, o elemento estratégico e estruturante da lógica colonial. Trata-se de uma violência que extrai sua originalidade na substantificação do colonizado que a própria situação colonial segrega e alimenta. Aliás, o encontro entre o colonizador e o colonizado, diz Fanon, teve sempre o retrato de violência e nunca foi expressão de uma vontade civilizadora ou humanizadora. Pode se ler em Fanon que a colonização é a categorização de um encontro que

se desenrolou sob o signo da violência e sua coabitação - ou melhor, a exploração do colonizado pelo colono - foi levada a cabo com grande reforço de baionetas e canhões [...] A violência [...] presidiu ao arranjo do mundo colonial, [...] ritmou incansavelmente a destruição das formas sociais indígenas, [...] arrasou completamente os sistemas de referências da economia, 
os modos da aparência e do vestuário do colonizado (Fanon, 1968, pp. 26 e 30 ).

É possível aproximar, em boa verdade, uma situação de uma clara alienação antropológica, fazendo fé à descrição de Fanon, a um projecto de civilização, sem cair em sofismas que desemboquem numa contradição? De notar que este mesmo entendimento de Fanon é corroborado pelo seu antigo mestre, Aimé Césaire, que parafraseamos nos seguintes termos: a colonização, enquanto violência, no sentido mais bruto da palavra, é uma autêntica antítese da civilização, ela, por natureza, desciviliza, simultaneamente, o colonizador e o colonizado. A colonização legitima o ilegítimo e normaliza o anormal: pode-se matar, à vontade, na Indochina, torturar em Madagáscar, prender na África negra, seviciar nas Antilhas... (cfr. Césaire, 1978, pp. 7 e 14). Não é preciso muita hermenêutica para apreender nos dizeres de Sartre de que a violência constitui o "modus operandi" próprio do sistema colonial que nem as suas geniais trapaças conseguem disfarçar. A peculiaridade do agir colonial distancia a colonização da civilização. E para deixar tudo a nu, Sartre faz a seguinte inconfidência:

\footnotetext{
"nossos soldados no ultramar rechaçam o universalismo metropolitano, aplicam ao género humano o numerus clausus; uma vez que ninguém pode sem crime espoliar seu semelhante, escravizá-lo ou matá-lo, eles dão por assente que o colonizado não é o semelhante do homem. Nossa tropa de choque recebeu a missão de transformar essa certeza abstrata em realidade: a ordem é rebaixar os habitantes do território anexado ao nível do macaco superior para justificar que o colono os trate como bestas de carga [...] nada deve ser poupado para liquidar as suas tradições, para substituir a língua deles pela nossa, para destruir a sua cultura sem lhes dar a nossa...” (Sartre, Les Damnés, 1961, p 9)
}

Esta violência que parte do plano simbólico conceitual atingiu o seu ponto auge com desterramento dos indígenas feitos estrangeiros na sua própria terra, como foi o caso do código civil 
imposto aos argelinos, visando regular o direito à propriedade e à herança com a única finalidade de desterrar os autóctones, tirandolhes o que de mais precioso tinha - a sua própria terra. De realçar que o referido código tinha aprovado a titularidade comum de terras entre a classe-média francesa e a sociedade tribal, como estratégia de expropriação de terras aos autóctones, através de políticas especulativas. (cfr. Sartre, 1967, p.39).

Desde este ponto de vista pode-se aferir que os "modus essendi et operandi" do colonialismo configuravam, em certa medida, aquilo que Sartre chamou de "imoralidade narcisista" da ambição ocidental da qual emerge o impulso que modifica, inevitavelmente, qualquer indivíduo que adere à dinâmica colonial, dando-lhe boa consciência e boas razões de ver no outro (não branco) um simples animal. Esta constatação sartriana valida, sem qualquer sombra de dúvida, a convicção de Césaire para quem o colonialismo é brutalidade, intimidação, crueldade, sadismo, choque, violação, roubo, desprezo, culturas obrigatórias, desconfiança, massas aviltadas, ausência de contacto humano, relações de dominação e de submissão que transformam o negro colonizado em criado, ajudante, comitre e instrumento de produção (cfr. Césaire, 1978, p.25). A partir destes pressupostos torna-se, de facto, forçoso concluir que não existe, tal como defende Fanon, qualquer sustentabilidade, quer argumentacional, quer factual para a validação da equação "colonização igual à civilização", pois os factos atestam que colonização é o oposto de civilização. Mas uma demarcha etimológica dos conceitos pode sugerir um outro entendimento que no plano teórico conceitual aproxima os dois conceitos em abordagem.

\section{Do entendimento teórico dos conceitos em análise a uma possível dedução da sua correlação}

Para fundamentar, com maior objectividade, o alcance da dedução decorrente da narrativa de Fanon em relação a 
conjecturada correlação entre os dois conceitos em análise, pareceunos mister recorrer ao estudo definicional dos referidos conceitos, no sentido de os tornar mais inteligíveis para, daí, depreender o seu justo significado e, consequentemente, confirmar ou infirmar a suposta correlação entre ambas. Convém, no entanto, sublinhar que o carácter polissémico dos conceitos em epígrafe não nos permite ignorar o facto de que não é tão fácil, quer do ponto de vista conceitual, quer do ponto de vista factual, traçar a linha de convergência ou de divergência entre eles, pois o próprio carácter multidisciplinar que o conceito de civilização envolve, hoje, conferelhe uma enorme complexidade que dificulta qualquer entendimento homogéneo, linear e conclusivo. Acresce-se a este dado o facto de que, nos dias que correm, o conceito de civilização é reivindicado como objeto de estudo da antropologia, da ciência, da cultura, do direito, da história, da filosofia política, da sociologia política, da religião, etc., proporcionando-lhe um enquadramento epistémico bastante complexo que recusa qualquer unicidade semântica. No entanto, um recuo estratégico e metodológico ao século das luzes, onde o significado do termo "civilização" emergiu da própria raiz etimológica do conceito - "civilis", "civis” - cujo entendimento remetia à ação de tornar civil ou urbano, pode permitir uma espécie de unidade de sentido a partir do qual se pode fundamentar a possível analogia conceitual destes dois termos.

A Enciclopédia Luso Brasileira da Cultura não foge muito desta percepção quando define a colonização como um fenómeno sociopolítico baseado na dependência de um grupo humano ou de um território a um outro que exerce nele influências demográficas, económicas, culturais, sociais ou políticas. Entendimento à luz do qual alguns teóricos, nos séculos XIX e XX, basearam a sua definição de colonização como atividade pela qual um povo de cultura superior ocupa e organiza, por conta própria, um território habitado por povos de cultura inferior, estendendo a sua soberania, desfrutando do solo e organizando as terras ocupadas, segundo o princípio da civilização. Observa-se, aqui, a missão civilizadora 
subjacente ao conceito da colonização, enquanto fenómeno sociopolítico, cuja meta é levar as colónias ao desenvolvimento cultural, social, económico e científico, ou seja, à modernização do território ocupado. Este é, de resto, o significado que decorre do entendimento filológico do conceito de colonização cuja estrutura originária se funda em torno de dois pressupostos basilares, nomeadamente: o cultivo da terra, isto é, o desenvolvimento económico, e o cultivo dos homens, ou seja, a promoção sociocultural e económica das populações consideradas na posição receptiva (cfr. Enciclopédia Luso Brasileira da Cultura, $\mathrm{n}^{\mathrm{O}} 5$, p.996ss).

De salientar que o conceito de civilização emergiu, e muito provavelmente, antes de qualquer outro país, no contexto sociocultural francês e fazia referência, essencialmente, a três dimensões que vale a pena enumerar: a primeira era referente ao primado da vida em comunidade sobre a vida solitária; a segunda fazia alusão ao primado da vida na cidade sobre a vida no campo; a última reportava-se ao primado do homem polido pela cultura sobre o selvagem, isto é, o homem moderno distinguido pela ciência e pela técnica, sobre o bárbaro (cfr. Enciclopédia LB da Cultura, $\mathrm{n}^{\mathrm{0}} 5$ ). Neste contexto teórico-conceitual, civilizar era, de facto, sinónimo de trabalhar na integração dos indígenas na comunidade metropolitana, na modernização da vida do campo, isto é, levando as condições da cidade ao campo (energia eléctrica, água potável, educação escolar, assistência médica e medicamentosa...) e na polição do bárbaro pela chamada "cultura”, científica e tecnológica.

Este parece ser o entendimento mais viável para o exame a que nos propusemos, da correlação destes dois vocábulos. O facto de esta mesma perspectiva encontrar suporte e sustentabilidade epistémica no Dicionário da Língua Portuguesa Contemporânea, editorial Verbo, acresce, ainda mais, o nosso interesse por esta perspectiva (cfr. 2001, p.833). Segundo o Dicionário, ora referenciado, a "civilização" é a acção ou o resultado de transmitir conhecimentos, comportamentos e técnicas consideradas desejáveis 
numa sociedade moderna. Por conseguinte, civilizar é dar características próprias de sociedades técnicas, científica e economicamente desenvolvidas a sociedades primitivas; ou, ainda, dar hábitos e ajudar a desenvolver comportamentos desejáveis numa sociedade desenvolvida. Conclui-se, pois, que, do ponto de vista conceitual ou definicional, existem razões para fundamentar a presumível correlação entre os conceitos de "colonização e civilização". Mas a não homogeneidade de compreensão na interpretação e aplicação destes conceitos, à partida, polissémicos e multidisciplinares, e o seu claro antagonismo factual evidenciado nas descrições fanonianas, obrigam-nos a dar um passo a mais, espreitando algumas doutrinas e factos que marcaram e continuam a marcar o discurso sobre o colonialismo.

\section{Da análise de algumas doutrinas e factos à uma possível verificação da equação de partida}

Se é possível aferir, do ponto de vista definicional, uma certa correlação analógica entre os conceitos que fundam a nossa equação de partida, tal como ficou patenteado no ponto anterior, do ponto de vista doutrinal e factual, esta correlação carece de uma análise minuciosa que permita apurar se a propensão civilizadora inerente ao conceito de colonização, pelo menos no plano teórico-conceitual, conseguiu vincar como aspecto norteador da acção colonial, ou terá, por alguma razão, ficado ofuscada durante o processo colonial. Impõe-se-nos, a este nível, retomar o ponto de vista de Fanon, para quem a colonização é, antes de mais, uma violência que se consubstancia na animalização e na aniquilação dos (negros) colonizados. Para sustentar o seu argumento, Fanon começa por relembrar a atitude do colono que, em várias circunstâncias, fez recurso a "uma linguagem zoológica, usando expressões como: “[...] hordas, fedor, bulício [...] e quando os quisesse descrever com mais exatidão [...] recorria constantemente ao bestiário" para designar os negros (Fanon, 1968, p. 31 ou 2002, p. 456). Esta animalização do 
colonizado é, para Fanon, a expressão mais eloquente de uma violência absoluta que desenraíza o aviltado de sua humanidade. E para reforçar a sua criatividade narcisista e alimentar o seu instinto nihilista, o colono via-se na necessidade de encontrar novos atributos que pudessem explicitar, da melhor maneira possível, a real dimensão semântica subjacente nos conceitos de "indígena e selvagem" que, em si, já não eram suficientes para exprimir a mesquinhez que representavam os selvagens negros de África, entre outros:

demografia galopante, massas histéricas, rostos de onde fugiu qualquer traço de humanidade, corpos obesos que não se assemelham mais a nada, corte sem cabeça nem cauda, crianças que dão a impressão de não pertencerem a ninguém, preguiça estendida ao sol, ritmo vegetal... (Fanon, 1968, p. 32 ou Fanon, 2002, p.457)

A validade histórica desta narrativa fanoniana suscita o seguinte questionamento: É sensato falar de um projecto de civilização de animais sem converter a própria racionalidade civilizadora numa irracionalidade animal? Para tentar justificar a paradoxal irracionalidade animal de uma civilização cuja racionalidade é o epicentro da sua acção, muitos preferiram considerar as afirmações de Fanon de irresponsáveis e repletas de inverdades, qualificando o próprio Fanon de agitador e instigador da violência, ante a sua incisiva caracterização do sistema colonial. Dentre outros, podemos citar Alain Finkierkraut, cujo pensamento, mais do que uma antítese às teses de Fanon, é uma tentativa de demonstração da derrota do projecto da descolonização; Pièrre Bourdieu, de quem procedem muitos dos adjectivos qualificativos que pesam sobre Fanon, é paradoxalmente considerado por Micheal Burawoy (2010, p. 109), como um dos autores que figuram da lista dos intelectuais como Albert Camus, Simone de Beauvoir, Germaine Tillion, Jasques Amrouche e outros que, como Fanon e Sartre, tiveram a ousadia de denunciar, cada um à sua maneira, a violência 
inerente ao sistema colonial, forjando novas noções de identidade política que continuam a influenciar o debate político na actualidade.

No seu "marxismo encontra Bourdieu", Burawoy procura mostrar que, apesar da enorme distância que separa o quadro teórico-reflexivo de Bourdieu e Fanon, nomeadamente "o marxismo terceiro-mundista, de um lado, e a teoria da modernização, de outro lado", o pensamento destes dois autores apresenta inúmeras similitudes, sobretudo, entre o Fanon do Le Damnés de la terre, de 1961, e o Bourdieu de Sociologie de l'Algerie, de 1958. Embora não seja objecto deste debate, julgamos oportuno e procedente mencionar, a título de exemplo, algum extracto da obra de Bourdieu que descreve a violência como uma das características intrínsecas à natureza própria do sistema colonial e nos termos muito semelhantes aqueles que aparecem nas páginas 26 e 30 do Le Damnés de la terre, de Fanon (cfr. 1968), ao afirmar:

o sistema colonial, enquanto tal, não poderá ser destruído senão através de um questionamento radical. Todas as mutações são submetidas à lei de tudo ou nada. Este facto está na consciência, pelo menos, de forma confusa, quer entre os membros da sociedade dominante, quer entre os membros da sociedade dominada [...] Mas é preciso admitir que o primeiro e único questionamento radical do sistema é aquele que o próprio sistema engendrou, isto é, a revolução contra os princípios que o fundaram [...] A situação colonial criou o desprezível e ao mesmo tempo o desprezo; mas criou, também, a revolta contra o desprezo. Assim, cresce, cada vez mais, a tensão que divide a sociedade no seu conjunto (Bourdieu, 1958, pp. 28 e 129).

Fica aqui o retrato de tanta similitude entre Fanon e Bourdieu, numa clara aproximação da colonização à violência. De facto, a violência simbólica e real é depreendida em muitos cenários e discursos sobre o colonialismo como uma marca distintiva do sistema colonial. Vários são os etnólogos e ideólogos que, nas entrelinhas do seu pensamento, conferem uma certa razão a um tal pressuposto. Alfred de Vigny, por exemplo, faz jus a esta violência 
simbólica ao afirmar, sem rodeios, que o mundo não europeu é um mundo animal, mundo dos bárbaros, mundo da morte e, consequentemente, uma ameaça ao mundo europeu. Partindo deste postulado, deduz-se que, para De Vigny, a colonização era um processo compulsivo de civilização, isto é, uma opção para a vida e, tal como diz "se se prefere a vida à morte, tem de se preferir a civilização à barbaridade", que não é apenas um reino animal e de morte, mas, também, uma ameaça à civilização. Em virtude disto, conclui De Vigny, "nenhum povo tem o direito de permanecer bárbaro ao lado das nações civilizadas". Depreende-se daqui que a única lógica válida é a disjuntiva, "to be or not to be", como diria Shakespeare, "that is the question" (cfr. De Vigny, 2003, p.87).

Esta apreciação lacónica de Alfred de Vigny ganha maior clareza com Folliet que, como De Vigny, também considera a colonização como uma obra civilizadora, uma espécie de direito e dever das sociedades evoluídas. Folliet baseia o seu argumento nas características heterogéneas das sociedades, isto é, nos desníveis existentes entre as sociedades colonizadas e colonizadoras, quer nos planos económico, administrativo, cultural, social e político, quer nos planos científico e tecnológico. Daqui resulta o entendimento segundo o qual a colonização seria, possivelmente, o processo de supressão destes desníveis sociais, com o auxílio das sociedades mais desenvolvidas. Pelo que a manutenção destes desníveis, como forma hegemónica de controlo ou de manutenção de superioridade, foge do âmbito da colonização para desembocar no campo de acção do colonialismo (cfr. Folliet, 1932, p. 75). É caso para dizer que o entendimento teórico de Folliet apresenta uma diferença nítida entre a colonização que seria, para o autor, o sinónimo de civilização e o colonialismo que pode ser visto como processo de exploração e subjugação das sociedades subdesenvolvidas pelas sociedades desenvolvidas.

Mas é preciso dizer que, se do ponto de vista conceitual, Folliet deu um tamanho salto qualitativo, propiciador de uma possível coabitação pacífica entre o colono e o colonizador, aludindo à missão 
civilizadora da colonização, do ponto de vista prático, o discurso follietiano deu lugar a muitas ambiguidades; sobretudo, quando o próprio autor considera a colonização como forma mais viável de se tirar o melhor proveito dos recursos naturais mal parados em territórios subdesenvolvidos e valorizá-los para o bem-comum da humanidade, sem definir as regras, nem as modalidades ou os vínculos contractuais para tal. Com efeito, Folliet considera um dado assente que "as nações economicamente mais evoluídas têm o direito de explorar as riquezas ignoradas ou desprezadas pelos povos selvagens" (Folliet, 1932, pp. 101 e 268). E para não camuflar a sua veia colonial consubstanciada no instinto de violência, Folliet defende a necessidade da manutenção das desigualdades entre o colonizador e o colonizado, numa clara opção pelo colonialismo em detrimento da colonização, contrariando a sua própria doutrina, com o seguinte posicionamento:

a desigualdade deve reinar a favor dos colonizadores, de modo que o sujeito colonizado não passe, numa vontade de vingança, a esquecer a sua heteronomia absoluta; é, portanto, útil e necessário que as mais vastas propriedades, as mais ricas indústrias, os mais frutuosos comércios pertençam aos representantes da raça superior (Folliet, 1932, p.228).

Uma possível dedução leva-nos, por um lado, a aferir a inadequação da equação de partida com os aspectos doutrinais e factuais tomados como pressupostos analíticos da questão em estudo e a considerar, por outro lado, a emergência da categoria de dominação como outro elemento característico da estratégia colonial na relação colonizado/colonizador. Este princípio que é, em si mesmo, o elemento estruturante da tensão e, ao mesmo tempo, provocador da dialéctica do senhor e do escravo, permite-nos um salto para o exame da possibilidade de um plano colonial de civilizar ou de modernizar a África em proveito dos africanos. 


\section{A colonização como projecto de modernização de África: clarividência ou equívoco?}

É possível compatibilizar o instinto de dominação com a vontade de promover ou de emancipar? Guillaume Suréna, num movimento contrário ao nosso itinerário, apresenta um discurso capaz de relançar a discussão. No seu artigo intitulado "Psycanalyse et anticolonialisme", Suréna lamenta o desperdício de uma oportunidade que teria resultado num possível encontro intercivilizacional frutífero, e que, no entanto, terá sido frustrado pela vontade dominadora do instinto colonial. Os textos surenianos insinuam que, do ponto de vista prático, a civilização europeia nunca teve qualquer plano de promover, nem de reconhecer as outras civilizações como parceiras importantes para um crescimento conjunto. A sua ambição foi sempre de conhecer para dominar e subjugar, como ficou explicitado nesta passagem:

este encontro de civilizações tão diferentes poderia ter sido o momento de um intercâmbio fecundo e de um enriquecimento mútuo, como lamentou o antropólogo francês Claude Levi-Strauss. Mas para a metafísica europeia, desde a Grécia antiga, o saber foi sempre o equivalente de "maitriser", isto é, de dominar. As coisas e os animais foram desbatizados para serem mutilados sob os conceitos com partículas latinas e gregas. Os locais geográficos receberam nomes que evocam a velha Europa e que os tornam ridículos por falta de qualquer relação com os espíritos que os habitavam outrora (Suréna, 1943, p. 4).

Diga-se, pois, de passagem, que foi assim na Grécia antiga, foi assim até ao século XX, e nada justifica que não continue assim nos dias que hão-de vir. Mas a questão é: qual o destino que o instinto dominador das nações pode proporcionar à espécie humana? Convém recordar que, num passado mais recente da história da Europa, a colonização assumiu o carácter de dominação dos povos e dos seus recursos naturais. Os europeus sempre mostraram-se mais interessados com uma partenogénese profunda dos africanos para 
os submeter mais facilmente e não para os civilizar. De facto, desde o início do século XVII, com as grandes navegações e os descobrimentos das américas, o interesse em explorar e conquistar novas terras ganhou um enorme vigor na Europa e, com ele, emergiu também a chamada colonização de exploração e de povoamento. A primeira forma de colonização foi o momento no qual prevaleceram os interesses mercantis no quadro em que as colónias tinham uma utilidade meramente lucrativa junto da metrópole. A segunda acontecia de maneira espontânea, mas tendo como factor motivacional o surgimento de uma actividade económica com garantias de melhorar a qualidade de vida de quem aí acorria.

Muitos estudos mostram que, no continente africano, este tipo de colonização foi sempre acompanhado de desterramento de zonas aráveis ou de pastagem dos autóctones, bem como da supressão dos eventuais direitos que detinham ${ }^{2}$. Embora referindose a um contexto muito mais pretérito ao de Fanon, Césaire, Sartre e outros, Iva Cabral traz ao de cima a ideia de dominação e de exploração como elementos catalisadores do interesse europeu em África, ajudando, assim, na desconstrução da hipótese de um possível plano colonial para o desenvolvimento de África e dos africanos. De facto, Iva Cabral afirma que a experiência ultramarina se resumia na conquista das praças do Norte de África e na fixação de guarnições e que os europeus arriscavam viver por tempo indeterminado nos territórios tropicais de África, não pelo desejo de levar a civilização às terras longínquas de África, mas por causa dos inúmeros privilégios económicos e sociais que tinham, os quais incluíam, em alguns casos, a sociedade escravocrata de produção no Atlântico (cfr. 2015, p.25).

Este suporte histórico que Iva Cabral empresta ao nosso argumento de tipo dedutivo encontra um reforço na posição de Sartre que introduz um outro elemento de enorme utilidade na

${ }^{2}$ Cfr. https://pt.wikipedia.og/wiki/colonização. Enciclopédia livre, 15/o2/2017 
nossa análise sobre as categorias de dominação e exploração como sustentáculos da acção colonizadora, quando, num tom autocrítico, apontando o dedo aos seus irmãos europeus, pinta, sem complexo nem contemplações, o verdadeiro retrato da Europa colonial, permitindo a apreensão da razão mais profunda e mobilizadora de toda a ofensiva opressão contra os autóctones em territórios colonizados, sobretudo em África, nestes termos:

sabeis muito bem que somos exploradores. Sabeis que nos apoderamos do ouro e dos metais e, posteriormente, do petróleo dos continentes novos e que os trouxemos para as velhas metrópoles. Com excelentes resultados: palácios, catedrais, capitais industriais [...] A Europa, empanturrada de riquezas, concedeu de jure a humanidade a todos os seus habitantes; entre nós lucramos com a exploração colonial (Fanon, 1968: p. 17).

Se tomamos a sério as diversas constatações dos autores supra mencionados, torna-se insustentável a hipótese de um suposto projecto de desenvolvimento colonial a favor dos africanos e da África, num contexto de exploração no seu sentido mais radical e mais bruto do termo, isto é, uma exploração não só de recursos naturais dos territórios colonizados, mas também do seu próprio capital humano. Num tal contexto, aproximar a colonização da civilização é admitir, à partida, uma ambiguidade semântica na compreensão destes dois conceitos. Reagindo a respeito de uma tal ambiguidade, Césaire diz que a colonização não deve ser confundida com uma empresa filantrópica, nem com uma nobre vontade de recuar as fronteiras da ignorância, da doença, da tirania e, até mesmo, da propagação de Deus e, muito menos, com uma política de extensão dos direitos do povo colonizado, como pretendeu o pedantismo cristão, que concebeu o referido equívoco, ao enunciar uma equação ética e religiosamente desonesta e politicamente pretensiosa: cristianismo igual a civilização e paganismo igual a selvajaria, tornando-se, assim, responsável pelas consequências 
abomináveis decorrentes dos actos coloniais, cujas vítimas seriam os índios, os amarelos e os negros (cfr. Césaire, 1978, pp.14-15).

Pode se depreender dos textos de Césaire que a colonização é a manifestação, sem precedente, da ganância do aventureiro e do pirata, do comerciante e do armador, do pesquisador de ouro e do mercado, do apetite e da força, tendo por detrás a sombra maléfica projetada de uma forma de civilização que, a dado momento da sua história, se viu obrigada, internamente, a alargar à escala mundial a concorrência das suas economias. Se não, como se pode perceber que a França, em particular, e a Europa, em geral, conseguissem, progressivamente, tal como alude Dino Constantini, transformar os princípios democráticos e humanistas, tão-reclamados naquela circunscrição do globo, em instrumentos de justificação de dominação, com regulares violações, nas colónias, dando lugar a uma degeneração sem precedente de uma suposta "missão civilizadora” da Europa em África (cfr. Constatini, 2008, pp. 33 e 53)? Para pôr a nu o paradoxo de uma civilização dita humanista, mas, na prática, contestadora da própria humanidade no "diferente", Constatini evoca o código civil de 1791, que coloca as colónias fora do direito comum, institucionalizando uma cisão social, juridicamente fundamentada, entre as populações brancas e negras, legitimando, ao mesmo tempo, a violência, primeiro, no plano simbólico e, posteriormente no plano concreto, numa clara declaração de recusa de reconhecimento e de integração dos negros na vida da metrópole. É preciso dizer que esta fragmentação social, legitimada pelo código civil supra citado, serviu de base para a consagração de uma nova compreensão do conceito da "humanidade" que reduziria os direitos humanos a direitos de cidadania, reservando-os apenas aos europeus.

É o paradoxo, no caso da França, de uma República que nunca deixou de contestar contra a violência de que tinha sido vítima em 1871, cegamente transformada numa autêntica máquina de violência contra outros humanos, sem qualquer fundamento legítimo (cfr. Constatini, 2008, p. 286). É a contradição de uma 
civilização ocidental defensora de direitos humanos, mas que não hesita de reduzir os outros humanos à categoria de sub-humanos; é a estratégia de um imaginário ideológico que, no plano psicológico, confere legitimidade a todas as barbáries dos colonizadores sobre os colonizados; é a ironia de uma civilização cuja linha de demarcação com a barbaridade não é explícita. Nem mesmo a dignidade humana, universal e abstracta, apregoada pelos moralistas desta civilização, como um dos valores mais sublimes entre os humanos, em especial, pela religião cristã, mais consagrada ao serviço do imperialismo do que de Deus, na óptica de Césaire, conseguiu dissimular a violência contra o colonizado.

\section{Desmistificando o mito de uma civilização humanista erguida na recusa do "diferente"}

Parece ter ficado evidente que a colonização se identificou mais com uma dinâmica de exploração dos povos colonizados do que com um projecto de integração dos indígenas na metrópole. Iva Cabral ajuda-nos, mais uma vez, a perceber como a lógica do lucro presidiu a todas as estratégias e legislações coloniais. Numa perspectiva simplesmente histórica, a autora apresenta alguns dados que nos permitem conferir uma certa validade a muitos dos enunciados de Fanon que concedem sentido e substância a este trabalho. Com efeito, Iva Cabral afirma que as decisões políticas do regime colonial criavam condições para que os filhos da média e baixa nobreza portuguesa, neste particular, mercadores e aventureiros vislumbrassem no território recém-descoberto uma oportunidade e um trampolim para o vasto mercado africano cujo acesso se abria na costa ocidental do continente e para os lucros que as mercadorias, daí advindas, poderiam trazer (cfr. Cabral, 2015, p.27).

É lógico conjecturar que, num tal jogo de lucro fácil, que não podia não contar com os recursos naturais e com o capital humano africanos, como meios ideais para minimizar os custos e maximizar 
os lucros, a preocupação pela integração dos africanos no clube dos evoluídos e emancipados seria uma espécie de atentado ao espírito de negócio. Este postulado encontra a sua sustentabilidade no discurso de Joseph de Maistre que radicaliza a atitude da recusa do "outro"- o diferente, feito uma ameaça para o "nós" ideologicamente construído e consagrado como o único paradigma possível de humanidade na seguinte declaração:

havia uma extrema verdade neste primeiro movimento dos europeus que se recusaram, no século de Colombo, em reconhecer seus semelhantes, homens degradados que povoavam o novo mundo [...] Era impossível fixar um instante do olhar no selvagem sem ler o anátema escrito, não digo somente na sua alma, mas, até na forma exterior do seu corpo (De Maistre, Joseph, Apud. Césaire, 1978, p. 33).

Esta declaração deixa transparecer uma inferência lógica quase irrefutável de que o referido anátema dos indígenas só não se consumou ao extermínio, na perspectiva do colono, por razões de índole puramente utilitarista, como se depreende nesta passagem do já citado autor nesta transcrição de Césaire:

sob o ponto de vista de selecção, consideraria deplorável o desenvolvimento numérico [...] dos elementos amarelos e negros, que seriam de eliminação difícil. Se, todavia, a sociedade futura se organizar numa base dualista, com uma classe dolico-loira dirigente e uma classe de raça inferior confiada à mais grosseira mão-de-obra, é possível que este último papel incumba aos elementos amarelos e negros. Neste caso, aliás, não seria um embaraço, mas uma vantagem para os dolico-loiros (De Maistre, Joseph, Apud. Césaire, 1978, p. 33).

Fica desvendado, nestes dizeres do De Maistre, o retrato do narcismo nihilista de muitos artistas da europa colonial, consubstanciado na ideia e na pretenção de uma raça superior que se julga no direito de combater todo o tipo de risco de contágio. É o drama de uma Europa feita refém pelo seu próprio mito de pureza 
civilizacional uniracial; um mito enganoso, pretensioso e pernicioso que põe em causa a aspiração de uma política enquanto exigência de construção de uma comunidade humana na qual a consciência da diversidade dos humanos e a necessidade da reciprocidade entre os diferentes se tornam uma condição "sine qua non" da prosperidade e da sobrevivência da própria espécie humana. Lamentavelmente, este entendimento da política como espaço intermediário onde se joga a liberdade e interacção dos humanos, enquanto seres iguais e autónomos é, constantemente, posto em causa, como diz Martha Nussbaum, pelos apologistas deste mito que, em todas as sociedades, alimentam uma falsa convicção de pureza etnocêntrica ou "classecêntrica", geradora de violência contra os excluídos (cfr. Nussbaum, 2010, p. 48), comprometendo a possibilidade de fazer da política o lugar por excelência da profundidade humana.

Para compreender as mais profundas motivações que levam os indivíduos a um tal instinto nihilista, Nussbaum recorre ao pensamento de Mahatma Gandhi, que examina a possível coneç̧ão existente entre os domínios psicológico e político. Com efeito, Gandhi concluíra que os desejos gananciosos, o instinto de agressão e a ansiedade narcisista são empecilhos para a edificação de uma verdadeira civilização humana. Pelo que a luta política pela construção de uma civilização humana, assente nos pilares da liberdade, empatia e igualdade deve ser precedida de uma luta contra o medo do outro, a ganância e o instinto de agressão narcisista intrínsecos em cada indivíduo (cfr. Nussbaum, 2010, pp. 48-50). E se partimos da hipótese de que o sucesso destas propagandas narcisistas que arrastam multidões ao ódio, ao genocídio e à instrumentalização dos "outros", tidos como da raça inferior ou sub-humana, ocorre mais em contextos de pouca capacidade crítica ou de uma intelectualidade materialista ou "ventríloque", usando a expressão de Fabien Eboussi Boulaga, isto é, de uma intelectualidade corrupta, desprovida de princípios éticos e humanistas, forçoso é concluir que por mais que a Europa colonial quisesse apostar num projeto de civilização dos africanos, não teria 
condições efectivas de o fazer ante a sua ganância e arrogância eurocentristas, encorajadas por uma jactância ostensiva feito veneno, instalado na veia de muitos europeus cegos pela avidez do lucro cuja solidificação se dá com o asselvajamento dos africanos, em geral, e dos negros, em particular.

É, precisamente, este instinto egoísta e materialista que transparece na maneira como Ernest Renan concebe o colonialismo. Para ele, o colonialismo é uma necessidade política de primeira ordem, é a conquista de um país de raça inferior pela raça superior que se instala na colónia através de um governo. Trata-se, na perspectiva deste autor, de algo de extrema normalidade que nada tem de chocante. A colonização só se torna chocante se, e somente se, as conquistas forem entre raças iguais. Assim, se, por um lado, estas conquistas devem ser desencorajadas e censuradas entre raças iguais, elas devem ser encorajadas entre as raças desiguais, porque a regeneração ou degeneração de raças inferiores pelas raças superiores deve estar na ordem providencial da humanidade. "Regere imperio populos", eis a nossa vocação. A natureza criou uma raça de trabalhadores industriais - é a raça chinesa, uma de jornaleiros agrícolas - é a raça negra [...], uma raça de senhores e de soldados é raça europeia”. Nesta óptica, a redução desta nobre raça à classe trabalhadora, em condições degradantes, como as dos negros e dos chineses, gera revolta (cfr. Renan, 1967, pp. 69-70). O mais perplexo em tudo isso é que Renan, numa enorme ousadia intelectual, não se tenha inibido do seu instinto de superioridade racial, ao defender, de forma paradoxal, numa obra intitulada "La Réforme Intellectuelle et Morale de la France”, a seguinte convicção:

nós esperamos não a igualdade, mas sim a dominação. O país de raça estrangeira deverá voltar a ser um país de servos, de jornaleiros agrícolas ou de trabalhadores industriais. Não se trata de suprimir as desigualdades entre os homens, mas de as ampliar e as converter em lei (Renan, 1967, p.69-70). 
Uma visão demasiado materialista e narcisista que mereceu, num tom irónico, a crítica de Césaire que qualifica o colono muito distinto, muito humanista e muito cristão do século XX como uma autêntica encarnação de Hitler. É o retrato do colono que traz em si, segundo Césaire, "um Hitler que se ignora, que vive nele e que é o seu demónio e se o vitupera é por falta de lógica ou pelo instinto de afinidade racial, pois os factos atestam que o que muitos deles não perdoam a Hitler não é o crime em si, nem tão-pouco o crime contra a humanidade, mas o crime contra o homem branco, a humilhação do homem branco". Assim, não restam dúvidas de que do ponto de vista do seu desenvolvimento socio-histórico, a colonização é uma suprema barbárie, um nazismo pouco expressivo por ser aplicado aos negros e aos árabes de África. Mas, na sua essência, um tal narcisismo constitui a negação mais eloquente do humanismo universal e formal, reivindicado por Fanon e, ao mesmo tempo, uma clara renúncia dos ideais filosóficos, morais e cristãos de uma civilização decaída (cfr. Césaire, 1978, pp. 18-19).

Está, assim, denunciada a patologia de uma civilização que fundou a sua filosofia de acção na estigmatização do "diferente" e na fragmentação do mundo em puro e impuro. É a construção patológica, usando a expressão da Nussbaum, de um "nós" que se julga imaculado e de um "eles" preconceitualmente denotado vil, perigoso e contagioso. Esta denunciada patologia obriga-nos a retomar algumas das questões supra referenciadas, tais como: é possível pensar a missão civilizadora da Europa colonial num contexto de clara recusa da alteridade ou de reconhecimento do africano como sujeito autónomo, dotado de razão e de humanidade? Como compreender uma missão civilizadora assente numa lógica social do segundo excluído, isto é, numa lógica social fracturante e nihilista? Será que África, ao engajar-se na luta pela descolonização, terá, efectivamente, recusado o projecto de desenvolvimento que configurava a missão civilizadora da potência colonial? Vamos no próximo ponto tentar encontrar alguns elementos de resposta a estes questionamentos, em certa medida, já respondidos. 


\section{A compartimentação maniqueísta, uma antítese à pretensão colonial da emancipação da África dos africanos}

A compartimentação maniqueísta da sociedade, ou seja, a bipolarização social assente no princípio da desigualdade entre as cidades dos homens, isto é, dos europeus e os bairros indígenas ou dos selvagens, categorias sociais criadas pelo próprio colono, contradiz, à partida, qualquer pretensão colonial de reconhecimento e integração da África e dos africanos no universalismo humano (cfr. Fanon, 1968, p. 27 ou 2002, p. 453). Aliás, a estrutura social montada pelo colono determinava, "a priori” que as relações entre os habitantes dos dois mundos fossem de exploradores e explorados, dominadores e dominados, opressores e oprimidos, superiores e inferiores, homens e sub-homens. Convém, no entanto, sublinhar que toda a violência colonial tinha como grande propósito a criação de um ambiente de medo e inibição do colonizado no intuito de facilitar a dinamização da exploração e a pilhagem de recursos naturais num contexto inovador de mercantilismo que muito precisava do concurso forçado dos próprios indígenas. Para dar conta do dinamismo interno de uma tal compartimentação maniqueísta Fanon, escreve:

em sua zona, o colono põe em marcha o movimento de dominação, de exploração e de pilhagem. Na outra zona, a coisa colonizada, oprimida e espoliada alimenta, como pode, esse movimento [...] as matérias-primas vão e vêm, legitimando a presença do colono. Enquanto o acocorado, mais morto do que vivo, o colonizado, se eterniza num sonho [...], o colono faz história. Sua vida é uma epopeia, uma odisseia (Fanon, 1968, p. 38 ou 2002, p. 463).

Como se pode depreender, mais uma vez, este maniqueísmo é, em si mesmo, uma antítese de qualquer projecto civilizador, não só pelo facto de se constituir num factor provocador de desprezo e ignomínia dos colonizados, mas também e sobretudo, por ser um 
factor desestabilizador, suscitador de ódio e de violência entre os habitantes das duas zonas. Cônscio desta tensão latente e subjacente a esta configuração geopolítica opressiva, o colono interpôs, como deduz Fanon, uma estrutura fronteiriça forte e intimidatória capaz de assegurar a atmosfera de submissão e de inibição dos explorados, tal como se pode ler:

o mundo colonizado é um mundo cindido em dois. A linha divisória, a fronteira, é indicada pelos quarteis e delegacias de polícia. Nas colónias o interlocutor legal e institucional do colonizado, o porta-voz do colono e do regime de opressão é o gendarme ou o soldado. Nas sociedades capitalistas, o ensino religioso ou leigo, a formação de reflexos morais [...] criam em torno do explorado uma atmosfera de submissão e inibição que torna consideravelmente mais leve a tarefa das forças da ordem [...] O intermediário do poder utiliza uma linguagem de pura violência [...] não torna mais leve a opressão, não dissimula a dominação. Exibe-as, manifesta-as com a boa consciência das forças da ordem [...] leva a violência à casa e ao cérebro do colonizado (Fanon, 1968, p. 28 ou Fanon, 2002, pp. 453-454).

Este e outros cenários permitem situar a originalidade do instinto colonial no princípio de diferenciação ontológica e social e no de desigualdade económica entre duas espécies: a branca e a negra ou árabe, pois, a patologia narcisista de superioridade racial estruturou, no imaginário individual e colectivo do colonizador, a convicção de que ser branco significa ser superior e, consequentemente, rico; e ser negro ou árabe africano é o oposto disto (cfr. Fanon, 1968, p. 29 ou Fanon, 2002, p. 455). Este maniqueísmo que toma balanço no plano simbólico no qual o branco remete à noção do bem, do belo e do bom e o negro o seu oposto, desembarca no plano concreto, com reflexos inofuscáveis, na configuração geográfica da estrutura social montada pelo regime colonial. A cidade do colono é uma cidade vida, enquanto no bairro do colonizado se sobrevive milagrosamente; a cidade do colono é segura, mas no bairro indígena a insegurança é o próprio cartão-de- 
visita; a cidade do colono é uma cidade sólida, toda de pedra e ferro, iluminada, asfaltada, as ruas limpas, lisas, sem buracos, mas o bairro indígena é o oposto disso. Na cidade do colono, os habitantes estão permanentemente saciados e repletos de boas coisas. Em contrapartida, o bairro indígena ou negro é um lugar mal-afamado e povoado, é o bairro de homens mal-afamados; aí, nasce-se, não importa como, nem onde e morre-se não importa a onde, nem de quê. É um mundo sem intervalos, ou seja, os homens estão uns sobre os outros, é o mundo dos famintos, dos analfabetos e dos doentes e indigentes (cfr. Fanon, 1968, p. 28-29 ou Fanon, 2002, pp. 453-454).

O mundo colonial, diz Fanon, forjou um povo sem alma e sem referência originárias. O colono criou categorias sub-humanas para destruir a autoestima dos negros e dos árabes de África. Fez deles uma espécie de quintessência do mal, considerando-os como seres impermeáveis à moral e à ética; com ausência e negação de valores; mal absoluto, elementos corrosivos que destroem tudo o que se aproxima deles; elementos deformadores que desfiguram tudo o que se refere à estética ou à moral; depositários de forças cegas. (cfr. Fanon, 1968, p. 31 ou Fanon, 2002, p. 456). Esta convicção levou M. Meyer a afirmar, em plena Assembleia Nacional Francesa, que:

[...] não era necessário prostituir a República fazendo penetrar nela o povo argelino. Os valores, com efeito, se tornam irreversivelmente envenenados e pervertidos desde que entram em contacto com a população colonizada. Os costumes do colonizado, suas tradições, [...] sobretudo seus mitos, são a própria marca desta indigência, desta depravação constitucional (Fanon, 1968, p.31 ou Fanon, 2002, p. 456).

Este discurso forjado no seu espaço existencial, levou Césaire (1978, p.17) à conclusão de que a Europa colonial se esmerou, antes de mais, em descivilizar: primeiro o próprio colonizador, embrutecê-lo, degradá-lo, despertá-lo para os instintos ocultos, para a cobiça, para a violência, para o ódio racial e para o relativismo 
moral e, posteriormente, descivilizar o colonizado. Todo este quadro legitima, sobremaneira, o anseio dos africanos pela liberdade e pelo reconhecimento da sua dignidade. Para desmascarar o argumento segundo o qual o engajamento dos africanos na luta pela descolonização de África terá sido uma espécie de recusa do desenvolvimento do Continente africano pelos africanos, Césaire passa em revista, e em jeito de balanço, o vasto fresco dos horrores da dominação colonial, em particular a francesa, em África, deixando claro que nenhum desenvolvimento vale mais do que a dignidade humana e o respeito pelos direitos e liberdades fundamentais dos povos. Apoiando o seu raciocínio nos factos. Com efeito, Césaire afirma que a equação mais ajustada à realidade vivida é colonização igual coisificação e não desenvolvimento, porque, no fim de contas, o fiel da balança pende mais para prejuízos do que para ganhos, tal como consta do longo extrato que extraímos do texto de Césaire:

falam-me de progressos, de realizações, de doenças curadas, de níveis de vida elevados acima de si próprios; eu falo de sociedades esvaziadas de si próprias, de culturas espezinhadas, de instituições minadas, de terras confiscadas, de religiões assassinadas, de magnificências artísticas aniquiladas, de extraordinárias possibilidades suprimidas. Lançam-me à cara factos, estatísticas, quilometragens de estradas, de canais, de caminhos-de-ferro; mas eu falo de milhares de homens sacrificados no Congo-Oceano, falo dos que, no momento em que escrevo, cavam à mão o porto de Abidjan; falo de milhões de homens arrancados aos seus deuses, à sua terra, aos seus hábitos, à sua vida, à dança, à sabedoria; falo de milhões de homens a quem inculcaram sabiamente o medo, o complexo de inferioridade, o tremor, a genuflexão, o desespero, o servilismo. Laçam-me em cheio aos olhos toneladas de algodão ou cacau exportado, hectares de oliveiras ou de vinha plantadas, mas eu falo de economias naturais, de economias harmoniosas e viáveis, de economias adaptadas à condição do homem indígena desorganizadas, de culturas de subsistências destruídas, de subalimentação instalada, de desenvolvimento agrícola orientada unicamente para benefício das metrópoles, de rapinas de produtos, 
de rapinas de matérias-primas. Ufanam-se de abusos suprimidos, eu também falo de abusos, mas para dizer que aos antigos - muito reais - sobrepuseram outros muito detestáveis. Falam-me de tiranos locais trazidos à razão, porém constato que, regra geral, eles fazem muito boa parelha com os novos e que, destes aos antigos e vice-versa, se estabeleceu, em detrimento dos povos, um circuito de bons serviços e cumplicidade. Falam-me de civilização, eu falo de proletarização e de mistificação [...] Cada dia que passa, cada negação de justiça, cada carga policial, cada reclamação operária afogada em sangue, cada escândalo abafado, cada expedição punitiva, cada polícia e cada miliciano fazem-nos sentir o preço das nossas velhas sociedades" (Césaire, 1978, pp.25-26)

Disso decorre que a essência do colonialismo, tal como realçou Mário Pinto de Andrade, reside em dois aspectos: no "regime de exploração desenfreada de imensas massas humanas, que encontra a sua legitimidade e sustentabilidade na violência" e na "forma moderna de pilhagem" (cfr. Césaire, Aimé, 1978, p.7). Assim, se os níveis científicos, tecnológicos e organizacionais ostentados pela Europa colonial lhe conferem, a todos os títulos, um estatuto de uma civilização, o mesmo já não se dá do ponto de vista da sua relação com as colónias. Por esta razão, Césaire chamou-lhe de civilização decadente, enferma e mórbida, por se ter revelado incapaz de resolver os grandes problemas que criou, nomeadamente, o do proletariado e o colonial. Ouçamos Césaire a respeito:

"uma civilização que se revela incapaz de resolver os problemas que o seu funcionamento suscita, é uma civilização decadente. Uma civilização que prefere fechar os olhos aos seus problemas mais cruciais, é uma civilização enferma. Uma civilização que trapaceia com os seus princípios é uma civilização mórbida” (Césaire, 1978, p.13).

Terão Fanon, Césaire, Sartre e outros exagerado na sua crítica do colonialismo? Possivelmente sim. Contudo, a larga unanimidade existente sobre o assunto permite-nos atribuir uma certa objectivdade e verdade histórica a muitos dos enunciados que nos 
são dados a apreciar. René Grousset (1954, p. 76), quase duas décadas antes de Césaire, analisando o percurso evolutivos das civilizações, constatava que nenhuma civilização apareceu, logo no início, tão promissora e tão ameaçada como a civilização ocidental. A sua ameaça, em seu entender, não vem apenas da espada nuclear, vem, também e sobretudo, do egoísmo e do materialismo que inspiram os povos que a comandam. Está, portanto, evidente que o regime colonial europeu foi, essencialmente, uma conquista assente em fins de exploração dos indígenas. Esta ideia césairiana de uma Europa exploradora, no sentido açambarcador do termo, aparece também no "Le génocide", no qual Jean-Paul Sartre é perentório em afirmar que a colonização não é uma mera conquista, como foi a anexação de Alsace-Lorraine, pela Alemanha; na sua verdadeira natureza, a colonização é um acto de genocídio cultural. Numa "démarche" fenomenológica, Sartre mostra que a colonização não acontece sem a liquidação sistemática de todas as características particulares de sociedades nativas e, simultaneamente, sem a recusa da sua integração massiva na metrópole e sem a negação do seu acesso às vantagens da metrópole.

Concordamos, assim, com Sartre que a colonização é um sistema de negócio que requer, inevitavelmente, a existência de um sub-proletariado nacional forçado a trabalhar por miseráveis salários. Vale dizer que, no sistema colonial, a colónia teve uma função instrumental, ou seja, foi usada para vender as suas matérias-primas e seus produtos agrícolas a um preço irrisório à metrópole. Em retorno, a metrópole vendeu os bens manufaturados às colónias a preço do mercado. Este negócio que contou com a comparticipação da burguesia nacional condenou os africanos a viverem num submundo de miséria como negros fantasmas, continuamente recordados da sua condição de sub-humanos (cfr. Sartre, 1967, p.39).

Está visto que a colonização, partindo da efígie aqui apresentada, é um projecto oposto aos ideais civilizacionais, tal como alude Césaire ao desmistificar a tentativa de atribuir ao 
processo de colonização uma intenção civilizadora. A maldição mais comum nesta matéria é deixarmo-nos iludir de boa-fé, por uma hipótese colectiva e hábil em enunciar mal os problemas para melhor justificar as soluções que se lhes aplicam, conferindo, facilmente, legitimidade a um conjunto de práticas abomináveis, atribuindo-lhes a categoria de um mal necessário com vista a um fim nobre - a civilização dos selvagens. (Césaire, 1978, p.14).

\section{Conclusão}

A reflexão feita nas páginas anteriores permitiu-nos deduzir a existência de uma possível analogia entre a colonização e a civilização do ponto de vista teórico conceitual. Mas, do ponto de vista prático, tudo não passou de uma simples ilusão. Uma ilusão cimentada pela fórmula do pedantismo cristão que procurou atribuir uma presumível missão civilizadora ao fenómeno de colonização, ao estabelecer a equação cristianismo igual a civilização e paganismo igual a selvajaria. A análise mostrou que, do ponto de vista doutrinal e factual, uma tal equação é insustentável, porquanto a colonização se assumiu mais como violência contra os povos colonizados e exploração dos seus recursos naturais e da sua força de trabalho e nunca como projecto colonial de emancipação dos povos colonizados. Esta conclusão pode ter sido previsível, mas, como foi referido no princípio deste trabalho, esta análise sobre o colonialismo encontra a sua utilidade neste texto, na medida em que se nos apresenta como movimento historicizante que constitui a matéria e a forma que nos permitem vislumbrar o horizonte teleológico da descolonização enquanto proposta de emergência do novo: nova realidade, novos seres e novo continente; uma espécie de antítese do mundo colonial. 


\section{Referências}

BOURDIEU, Pierre. Le Sens Commum: Chose dites. In: Fildwork in philosophy, Paris, Les Éditions de Minuit, 1987;

BOURDIEU, Pierre. Sociologie de l'Algerie. Paris, PUF, 1958.

BURAWOY, Michael. Marxismo encontra Bourdieu Campinas, Editora Unicamp, 2010.

CABRAL, Iva. A Primeira Elite Colonial Atlântica: Dos "homens honrados broncos" de Santiago à "nobreza da terra”. Finais do séc. $X V$ - início do séc. XVII, Cabo Verde, Pedro Cardoso Livraria, 2015.

CÉSAIRE, Aimé. Discurso sobre a colonização, Lisboa, Livraria Sá da Costa Editora, 1978.

CONSTATINI, Dino. Mission civilisatrice: le role de l'histoire colonial dans la construction de l'identité politique française, Paris, Éditions de la Découverte, 2008.

DE VIGNY, Alfred. "Critique des anedotes historiques sur Alger de Jean-Toussaint de Merle", In: Bancel Nicolas, Blanchard Pascal, Verges Françoise. La Republique colonial. Paris, Albin Michel, Coll. Pluriel, 2003.

Dicionário da Língua Portuguesa Contemporânea, Academia das Ciências de Lisboa, Editorial Verbo, 2001.

Enciclopédia Luso Brasileira da Cultura, Editorial Verbo, Lisboa, $\mathrm{n}^{\mathrm{o}} 5$

FANON, Frantz. Frantz Fanon Ouevres, Paris, Éditions La Découverte, 2011.

. Les damnés de la terre, Paris, Éditions la Découverte, (Préface de Jean-Paul Sartre), 1961.

- Os condenados da terra, Rio de Janeiro - Brasil, Civilização Brasileira, Tradução de José L. de Melo, 1968.

FOLLIET, Joseph. Le droit de colonisation: Étude de morale sociale et international, Lyon, G.Neveu, 1932. 
98 | Revista Opinião Filosófica, Porto Alegre, V. 09; Nº. 01, 2018

GIRARD, René. La Violence et le Sacré, Paris, Grasset, réé. Pluriel, 1972;

GROUSSET, René. L’homme et son histoire, Paris, Plon, 1954.

NUSSBAUM, C. Martha, Not For Profit: Why Democracy Needs The Humanities, Oxford, Princeton University Press, 2010.

OLÚFÉMI, Táiwo. "Post-Independence African Political Philosophy". In: Kwasi Wiredu. A Companion to African Philosophy. Cornwall, MPG Books Ltd, Bodmim, 2004, pp. 243-260.

RENAN, Ernest. La Réforme Intellectuelle et Morale de la France, Paris, Union Générale d'Éditions, 1967.

SARTRE, Jean-Paul. "Le Genocide", In: Les Temps modernes, $\mathrm{n}^{0}{ }^{259}$, Gallimard, Decembre, 1967.

SEMELIN, Jacques. Purifier et Détruir: Usages politiques de massacres et génocides, Paris, Seuil, 2005.

SENGHOR, Leopold Sedar. On African Socialism. London, Pall Mall Press, 1964. 